\title{
Is Thai Banking Ready for AEC Financial Liberalization in 2020?
}

\author{
Pornpen Vora-Sittha ${ }^{1}$ \\ ${ }^{1}$ Center for AEC Capability Research, Research Center, Nation Institute of Development Administration \\ (NIDA), Thailand \\ Correspondence: Pornpen Vora-Sittha, Center for AEC Capability Research, Research Center, Nation Institute of \\ Development Administration (NIDA), Thailand. E-mail: pornpen_econ@yahoo.com
}

Received: March 23, 2016 Accepted: March 29, 2016 Online Published: April 19, 2016

doi:10.5539/ass.v12n5p226 URL: http://dx.doi.org/10.5539/ass.v12n5p226

\begin{abstract}
Thai banking's readiness before approaching a new phase of regional economic integration under AEC's Financial Liberalization in 2020 is evaluated through the applications of Financial Development Index (FDI), developed by World Economic Forum (WEF). The paper assesses bank's readiness for regional competition by using readiness index constructed in this study. Data limitation allows this article to cover only six countries in ASEAN, namely, Indonesia, Malaysia, Philippines, Singapore, Thailand, and Vietnam. The analysis includes four pillars and one sub-pillar out of 7 pillars representing the whole financial system. Results show that Singapore's banking system is the readiest country for regional competition, followed by Malaysia, Thailand and Philippines. The banking sector in Thailand is not quite ready for AEC financial liberalization. The pillars that weaken Thai banking system are the "Institutional environment" and the "Business environment". The country needs to improve these two pillars to foster its competency for AEC challenges.
\end{abstract}

Keywords: Thailand, bank, ASEAN Economic Community (AEC), financial liberalization, regional economic integration, bank readiness

\section{Introduction}

\subsection{Why the Banking Sector Is Important?}

Thailand as a member of ASEAN Economic Community (AEC) is now approaching a new phase of regional economic integration. The adoption of AEC in 2015 will deepen economic integration regarding the free movement of goods, services, investments, and people. For service sector, the ASEAN Banking Integration Framework (ABIF) is expected to come into effect by 2020. Financial Integration among AEC is imperative. ASEAN banks and other financial institutions are not large in asset size to compete effectively against global players in international financial markets, and they are vulnerable to shocks from outside the region (Asian Development Bank, 2013). It is expected that the integration will help pave the way for the entry of regional banks into domestic markets, and improve ASEAN banks competitiveness against foreign banks. However, the AEC can give both positive and adverse effects to banking sector of the country members. Bank may benefit from market expansion through the increasing in cross - border financial and trading activities as well as revenue remittance. Meanwhile, a freer movement of capital among member states also induce higher competition and more risk exposure due to capital outflows, sharp currency depreciation, emerging inflationary pressures and tightening financial conditions, which could dampen economic growth.

To make Thai banking sector stay resilience and competitive in the more open market; it is necessary to be aware of the strength and weakness of the Thai banking system, and to identify country positions and strategy in responding to its impacts. This paper intends to evaluate the readiness of Thai banking for regional competition before approaching a new phase of AEC economic integration. A study of the readiness of banking system is essential because commercial banks are the most dominant sector of the financial system in the ASEAN countries, as well as, Thailand.

\subsection{Review of Previous Study}

The degree of competition can be measured by the actual behavior of bank conduct. Empirical research on competition in the financial sector has been scarce and the extent available is still at an early stage. To date, greater competition has been achieved by traditional means: removing entry barriers, liberalizing product restrictions, abolishing restrictive market definitions, eliminating intra-sectoral limitations, (Claessens, J.2009) 
and reducing government activity restrictions to enhance financial accessibility (Beck, Asli, and Vojislav; 2004). The Later concept in a broader perspective about factors determining competitiveness was pointed out by Claessens, J. (2009) that - there are so many factors that are driving competition in the financial sector; it is not sufficient to analyze competitiveness from a narrow concept alone or focus on one effect only. He suggested that competition has to be considered as part of a broad set of objectives, including financial sector efficiency, access to financial services for various segments of users, and systemic financial sector stability, and consider possible trade-offs among these objectives. Therefore, when trying to increase competition in the financial sector, it is essential for a policymaker to consider a broad set of policy tools instead of any particular factor.

Several previous studies assessed and explained the readiness situation of banking integration in ASEAN. Asian Development Bank (2013), for example, determine the current state of banking market integration in ASEAN to show their readiness and also assess their compatibility with regulatory systems among the countries, while some studies put their focal point on readiness to fulfill countries' commitments to ASEAN Framework Agreement on Services (Wai-Mun, Teck-Heang, \& Cai-Lian, 2011). There have been only a few country studies that answer whether the country is ready for regional competition under ASEAN Financial Liberalization. This paper will evaluate the readiness of banking sector for Thailand by constructing readiness index, using the scores and ranks in FDI (Financial Development Index) developed by WEF (World Economic Forum). The FDI is selected for this study because it is one of a complete datasets for analyzing competitiveness of banking sector to date.

\subsection{Background}

\subsubsection{Country Background}

The AEC as a collection of ten member countries has a combined population of approximately 625 million people, $8.8 \%$ of the world's population. ASEAN has the world's third largest labor force that remains relatively young. In 2015, the combined nominal GDP is expected to grow more than US\$ 2.2 trillion, ranked as the eighth largest economy in the world (Note 1).

Thailand is currently considered a newly industrialized country and is the second largest economy in Southeast Asia after Indonesia. Among the six countries studied, Thailand is ranked the third richest nation regarding GDP per capita and the major type of financial assets to GDP after Singapore, and Malaysia (Table 1).

\subsubsection{Financial Background}

Unlike EEC, there will be no regional central bank among AEC members. Commercial banks of each country will still be supervised and regulated mainly by their central bank, whereas special-purpose banks and nonbank financial institutions are under different regulatory agencies.

Table 1 shows that Malaysia and Singapore have much higher levels of financial depth than Thailand and the rest of AEC. Only Thailand and Vietnam is a bank- based system; holding their wealth regarding banking deposits, compared to the rest of countries which hold equity and bonds as their major financial assets.

Table 1. Selected key ASEAN macroeconomic indicators

\begin{tabular}{lcccccc}
\hline \multicolumn{1}{c}{ Key indicators } & Indonesia & Malaysia & Philippines & Singapore & Thailand & Vietnam \\
\hline Population (millions), 2011. & 241 & 28.7 & 95.9 & 5.3 & 64.1 & 89.3 \\
GDP (US\$ billions), 2011 & 845.7 & 278.7 & 213.1 & 259.8 & 345.6 & 122.7 \\
GDP (current prices) per capita, 2011 & $3,509.00$ & $9,700.00$ & $2,223.00$ & $49,271.00$ & $5,394.00$ & $1,374.00$ \\
Total Financial assets by major type/GDP,2010 & $117.10 \%$ & $434.90 \%$ & $193.90 \%$ & $432.50 \%$ & $248.80 \%$ & $168.00 \%$ \\
Total debt securities (\%) & 25.54 & 29.37 & 30.99 & 32.3 & 23.84 & 34.14 \\
Banking deposits (\%) & 31.01 & 30.94 & 28.35 & 30.08 & 41.17 & 54.14 \\
Equity securities (\%) & 43.44 & 39.69 & 40.66 & 37.63 & 34.99 & 11.72 \\
Total (US\$ bn) & 829.6 & $1,034.30$ & 386.9 & 983.4 & 793.6 & 174 \\
\hline
\end{tabular}

Source. Country/Economy Profiles in the Financial Development Report 2012, p. 148, 188, 224,248, 276 and 304.

The AEC size of assets in the financial sector is rather small, resulting in the low efficiency and weak international competitiveness. Banks are by far the most important type of financial institutions in ASEAN.

Table 2 shows that commercial bank in ASEAN held largest assets with the average share of $76.7 \%$ of the total compared to other financial institutions. It is expected that the integration of banking sectors in ASEAN will contribute to an enlargement of bank size through expansion of their customer base, lowering of price for bank services which will finally help foster an "inclusive growth" in the region. 
Table 2. Total assets of ASEAN financial institutions

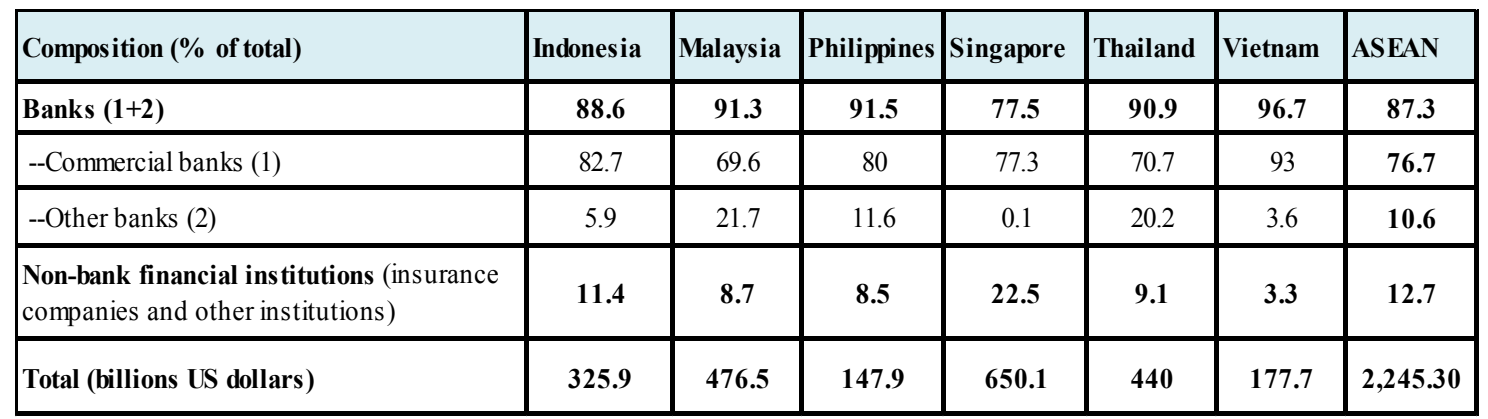

Note. All data except for Brunei Darussalam was for end-2009; end-2010 for Brunei Darussalam only.

Sources. Official websites and annual reports of ASEAN central banks and financial supervisory agencies.

Concerning the number of financial institutions, there are 368 commercial banks in ASEAN countries in $2012 / 2013$ (Table 3 ). More than half of them are from 2 countries; Indonesia $(24.54 \%$ ( and Singapore $(27.52 \%)$. For Thailand, there are only 31 commercial banks in operation, ranked the $5^{\text {th }}$ in AEC.

Around 53.90 percent of the commercial banks in AEC are foreign owned banks, either partial or whole. Most of them are in Singapore and Indonesia. Singapore government liberalized the banking sector by awarding greater liberty for foreign banks to operate in Singapore since 2001 (Hawksford, 2015). Indonesia, on the other hand, had allowed foreign investors to hold local banks equity up to $99 \%$. Foreign banks got permission to locate their branches freely within Indonesia territory as a measure to rescue the monetary and banking system as well as the economy during Asian financial crisis of 1997-98 and the previously settle during the crisis is still in operation (Sato, 2005).

Table 3. Number of financial institutions in ASEAN member countries

\begin{tabular}{ccccccccc}
\hline & Indonesia & Malaysia & Philippines & Singapore & Thailand & Vietnam & ASEAN (10) & $\%$ \\
\hline Commercial banks & 107 & 31 & 20 & 120 & 37 & 53 & 368 & 100 \\
Public banks & 4 & 8 & 3 & & 7 & 6 & 28 & 8.72 \\
Private banks & 56 & & 17 & 3 & & 37 & 113 & 37.39 \\
$\begin{array}{c}\text { Foreign own banks } \\
\text { (whole/partial) }\end{array}$ & 47 & 23 & & 117 & 30 & 10 & 227 & 53.90 \\
$\begin{array}{c}\text { Quasi-banks } \\
\text { (Subsidiaries/Agency) }\end{array}$ & 23 & 50 & & & 15 & 96 & 184 & 100.00 \\
\hline
\end{tabular}

Note: All data presented in table are in 2012/2013 except 2011 for Vietnam

Source: Official websites and annual reports of ASEAN central banks and financial supervisory agencies.

\section{Method}

\subsection{Conceptual and Operational Definition}

Forming ABIF is expected to improve ASEAN banks competitiveness against foreign banks. However, the entry of regional banks into domestic markets will also increase competition in allocating country's savings. Connectivity of financial services among countries in AEC transfers both benefits and cost to each other and competition among member countries within the region is unavoidable. Cross- border financial contagion can be a potential risk for countries whose financial system does not well prepare for integration.

Given the degree of financial competitiveness among countries, several studies come up with the solution that in fostering sustainable financial development and improving the performance of financial systems, there should contain numerous institutional factors and stakeholders. The WEF, for example, defines country competitiveness as the set of institutions, policies, and factors that determine the level of productivity of a nation. The productivity, in turn, sets the level of prosperity and degree of competitiveness for the financial system (WEF, 2013). The definition imposed by WEF is also consistent with Claessens (2009) and the Global Financial Development Report (the World Bank, 2013).

In assessing the readiness for competition among banking in AEC, this study uses "Readiness Index" as an indicator. The "Readiness Index" includes the variables that manifest both short run and long- run 
competitiveness features. This study presumed that scores and ranks of Financial Development Index reflect only the short run competitiveness of banking system. For the long- run competition, this study used two sets of variables underlining each pillar: the ratio of advantage to disadvantage variables for financial development, and the trend of the scores for long-run measurement. Assume that a country with a high ratio of advantage to disadvantage variable indicates more readiness to face regional economic integration under AEC's Financial Liberalization than a country with a lower ratio. Similarly, a country with a high ratio of increasing trend variables to decreasing trend variables would also display more readiness in the banking sector than a nation with a lower ratio. Therefore, a country with the highest ratio of advantage to disadvantage variable in accompany with the highest ratio of increasing trend variables to decreasing trend variables will be the most readiness for competition in the long run (Figure 1)

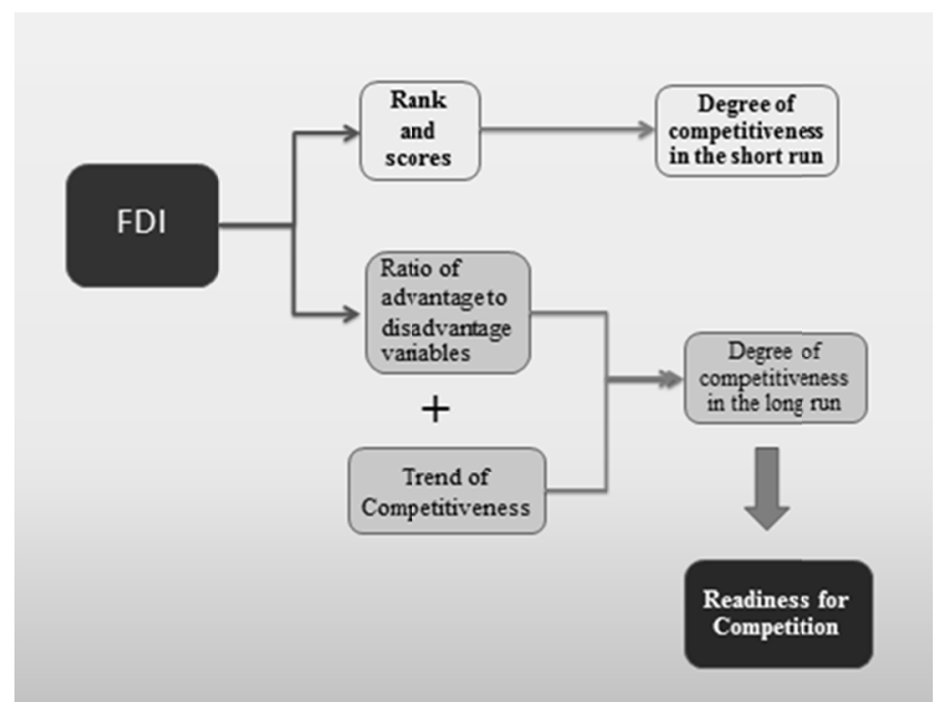

Figure 1. Framework for computing readiness index

\subsection{The Data and Scope of Study}

This study used the "Financial Development Index (the Index)" derived from the Financial Development Report of WEF as a proxy for the degree of competitiveness among bank in the countries studied. The Index was employed in this study because it provided scores and ranks of 62 world's leading financial systems and capital markets, covering the most variety of dimensions in the financial sector; as of 121 variables in 7 pillars, compared to other sources. In addition to the FDI, indicators considered compatible with the FDI are found in the "Financial Sector Development Indicators (FSDI)" that offered by the World Bank. Even though the FSDI also provided the set of data as the basis for assessing a country's overall financial sector, especially when benchmarked against international, regional, or cross-country standards. The indicators are grouped into only four broad dimensions: (1) Size; (2) Efficiency; (3) Access; and (4) Stability.

Data limitation of the Report allows this study to cover ASEAN communities cover only six countries, namely, Vietnam, Malaysia, Singapore, Indonesia, Philippines, and Thailand. The rest of them in AEC members not included are Brunei, Republic of Laos, Cambodia, and Myanmar.

In the Report, various aspects of the impetus for financial development can be seen as seven pillars, grouped into three broad categories with 25 indicators as shown in Appendix A.

\subsection{Methodology}

The Index used in this study comprised of three sets of indicators. Firstly, scores and ranks in the Financial Development Report developed by World Economic Forum (WEF) in 62 countries in 2012 were used to compare the degree of competitiveness among ASEAN community in the short run; the Financial Development Report in 2012 was the latest data available from WEF to date. Secondly, the number, as well as, the computed ratio of advantage and disadvantage variables to financial development of the country was utilized to investigate the driving forces supporting banking sector of Thailand compared to other ASEAN countries. Thirdly, the time series of FDI during 2009-2012 were used to analyze the trend of competitiveness for each country in the long run. Fourthly, the second and third indicators were combined to construct "Readiness Index" which showed the 
stage of Thai banking readiness for competition under financial openness in the long run.

\section{(a) Indicators}

This paper assesses bank readiness for competition by using only indicators that related to the banking sector. Only five out of seven pillars were selected and grouped into two sets of indicators. Set A (Supporting Indicator) contained three pillars which reflected basic features that supporting the banking system which are pillar 1 (Institutional environment), pillar 2 (Business environment), and sub-pillar 3 (Banking system stability)

Set B (Banking Indicator), on the other hand, included two pillars which directly related to bank sector (pillar 4 and pillar 7), as shown in Table 4. Of the five pillars studied, there are altogether 79 variables included in 17 sub-pillars.

Table 4. Financial indicators explaining the readiness for competition

\begin{tabular}{ll}
\hline A. Supporting Indicator & B. Banking Indicator \\
\hline 1st pillar: Institutional environment & The 4th pillar: Banking financial services \\
Financial sector liberalization & Size index \\
Corporate governance & Efficiency index \\
Legal and regulatory issues & Financial information disclosure \\
Contract enforcement & 7th pillar: Financial access \\
2nd pillar: Business environment & Commercial access \\
Human capital & Retail access \\
Taxes & \\
Infrastructure & \\
Cost of doing business & \\
3rd pillar: Financial stability & \\
Banking system stability & \\
\hline
\end{tabular}

\section{(b) Criteria for Identifying the Index Variables}

The Financial Development Report imposed criteria in identifying the Index variables as advantages or disadvantages to financial development of a nation. The Report (2012) hypothesizes that a variable is advantages to the financial system if its rank is better than the country ranking; implying that it help drives the country financial development forward, and is disadvantaged if its development is lag behind the country ranking. Following the Report, the rules identifying variables as advantages or disadvantages in this study are presented in Table 5.

When the variable is specified whether it constitutes an advantage or a disadvantage role for the country development through the financial system, such an approach will allow decision-makers to develop a balanced perspective in determining which aspects of their country's financial system are most important, and which aspects need improvement.

Table 5. Criteria for identifying the index variables

\begin{tabular}{|c|c|c|c|c|c|c|}
\hline Rank of FDI & Indonesia & Malaysia & Philippines & Singapore & Thailand & Vietnam \\
\hline Rank of Country Financial Development Index & 50 & 18 & 49 & 4 & 34 & 52 \\
\hline Rank for Advantage Variables & $1-31$ & $1-17$ & $1-31$ & $1-10$ & $1-31$ & $1-31$ \\
\hline Rank for Disadvantage Variables & $32-62$ & $18-62$ & $32-62$ & $11-62$ & $32-62$ & $32-62$ \\
\hline
\end{tabular}

Source: The Financial Development Report 2012, World Economic Forum USA Inc. New York, USA., p. 58

\section{(c) Trend of Competitiveness}

Financial Development Index during 2009-2012 was used to analyze the trend of competitiveness for each country. The trend variable can be calculated by using equation (1) as follow:

$$
\operatorname{Trend}_{\mathrm{i}}=(\text { Score in 2012) } \mathrm{i}-(\text { average scores of 2009-2001) } \mathrm{i}
$$

Where; Trend $=\mathrm{D}$ (Decreasing), if the sign is negative.

$$
=\mathrm{I} \text { (Increasing), if the sign is positive. }
$$




$$
\begin{aligned}
& =\text { Unchanged, if the difference is zero. } \\
& \mathrm{i}=\text { Country " } \mathrm{i} \text { " }
\end{aligned}
$$

\section{(d) The Readiness Index}

The "Readiness Index" displayed two dimensions of banking competitiveness. It indicated whether the trend of each pillar (and variables within the pillar) were rising or declining during 2009-2012, and also shows whether each pillar (including variables within the pillar) were advantages or disadvantage for banking development. A pillar/variable was considered ready for financial liberalization challenges if it had a rising trend and was advantageous for financial development (A1). For a pillar/variable that was ranked worse than country rank but its scores during 2009-2012 was rising, it will be in a rather ready situation (A2). In the opposite situation, a pillar/variable with declining trend was considered risky in losing their competitiveness in the long run; the condition was classified as " rather risky (B1)" and "risky (B2)" conditions (Table 6).

Table 6. Criteria for classifying pillar and variable readiness of competition

\begin{tabular}{ccc}
\hline \multirow{2}{*}{ Trend } & \multicolumn{2}{c}{ Development Challenges } \\
\cline { 2 - 3 } & advantage & disadvantage \\
\hline Rising & ready (A1) & rather ready (A2) \\
Declining/Stable & rather risky (B1) & risky (B2) \\
\hline
\end{tabular}

\section{Results of the Study}

This paper evaluated the readiness of Thai banking sector in comparison with Indonesia, Malaysia, Philippines, Singapore, and Vietnam. Presentation of results was in two parts. The first part analyzed the degree of competitiveness in banking services among ASEAN countries in the short run perspective. The second part introduced the computed ratio of advantage and disadvantage variables to compare the strength of driving forces that supporting banking sector of ASEAN countries. The following sections showed results of competitiveness computed from equation (1). Lastly, the "Readiness Index" was used for evaluating whether Thai Banking is ready for competition under financial openness in the long run.

\subsection{Competitiveness of AEC Banking in the Short Run}

This study used scores and ranks in the FDI developed by WEF (World Economic Forum) in 2012 to display competitiveness of the financial system of each country in the short run. The results showed that there were only two out of six ASEAN countries that their scores rank top 20 of the world; they were Singapore (4th) and Malaysia (18th). Thailand was ranked third in ASEAN at the 34th, where Philippines, Indonesia, and Vietnam stayed at the last quartile of the world (Table 7).

Among the six countries, Singapore scored best in every pillar and maintained its position at the fourth in the World 2012's Index. Singaporean bank was dominant among highly developed banking in the world market and was hard for Thailand to challenge. Banks in Indonesia, Vietnam, and the Philippines, on the other hand, had large populations and had relatively small banking sectors. Therefore, the only challenge for Thai bank in AEC to catch up with in the future is Malaysian bank that by far is much stronger than the commercial banks in Thailand.

Table 7. Ranks in FDI 2012 among 6 ASEAN Members

\begin{tabular}{lcccccc}
\hline & Indonesia & Malaysia & Philippines & Singapore & Thailand & Vietnam \\
\hline Rank of FDI 2012 & 50 & 18 & 49 & 4 & 34 & 52 \\
A. Supporting Indicators & & & & & & \\
Pillar1: Institutional environment & 51 & 21 & 39 & 1 & 33 & 53 \\
Pillar 2: Business environment & 53 & 25 & 54 & 1 & 45 & 56 \\
Subpillar 3: Banking system stability & 48 & 29 & 54 & 8 & 56 & 46 \\
B. Banking Indicators & & & & & & \\
Pillar 4: Banking financial services & 53 & 11 & 49 & 10 & 28 & 32 \\
Pillar 7: Financial access & 54 & 28 & 53 & 14 & 25 & 43 \\
\hline
\end{tabular}

Note: Shaded pillar represents indicator that is the disadvantage to financial development, and unshaded pillar stands for the indicator that is the advantage of financial development. 


\subsection{The Computed Ratio of Advantage and Disadvantage Variables}

Following the criteria of WEF in identifying variables as advantages or disadvantages to country development; of the five pillars, there were altogether 79 variables that explain the degree of bank competitiveness. When categorizing the variables into two groups; the advantage and the disadvantage ones as shown in Table 8, the results indicated that only banking sector of Singapore constitutes more advantage than disadvantage variables, reflecting the country's strength for competition and readiness in facing regional economic integration under AEC's Financial Liberalization.

Table 8 . Ratio and number of advantage and disadvantage variables categorized by country and by pillar in 2012

\begin{tabular}{|c|c|c|c|c|c|c|c|}
\hline \multirow{2}{*}{$\begin{array}{c}\text { Indicator } \\
\text { Set }\end{array}$} & Financial Development Index & Indonesia & Malaysia & Philippines & Singapore & Thailand & Vietnam \\
\hline & \multicolumn{7}{|c|}{ Ratio of Advantage to Dis advantage Variable } \\
\hline A & 1st pillar: Institutional environment & 0.3 & 0.86 & 0.44 & 4.2 & 0.44 & 0.24 \\
\hline A & 2nd pillar: Business environment & 0.29 & 0.47 & 0.22 & 2.14 & 0.16 & 0.1 \\
\hline A & 3rd pillar: Banking system stability (subpillar) & 1.5 & 1.5 & 0.25 & 1.5 & 0.67 & 0.67 \\
\hline $\mathrm{B}$ & 4th pillar: Banking financial services & 0.4 & 0.75 & 0.4 & 1.33 & 2.5 & 1.33 \\
\hline \multirow[t]{2}{*}{$\mathrm{B}$} & 7th pillar: Financial access & 0.71 & 3 & 0.71 & 1.4 & 3 & 0.33 \\
\hline & \multicolumn{7}{|c|}{ Total Number of Variables in Each Pillar } \\
\hline A & 1st pillar: Institutional environment & 26 & 26 & 26 & 26 & 26 & 26 \\
\hline A & 2nd pillar: Business environment & 22 & 22 & 22 & 22 & 22 & 22 \\
\hline A & 3rd pillar: Banking system stability (subpillar) & 5 & 5 & 5 & 5 & 5 & 5 \\
\hline $\mathrm{B}$ & 4th pillar: Banking financial services & 14 & 14 & 14 & 14 & 14 & 14 \\
\hline \multirow[t]{2}{*}{$\mathrm{B}$} & 7th pillar: Financial access & 12 & 12 & 12 & 12 & 12 & 12 \\
\hline & Total Number of Variables & 79 & 79 & 79 & 79 & 79 & 79 \\
\hline
\end{tabular}

Note. a) Ratio $\mathrm{X}_{\mathrm{ij}} \quad$ = Number of advantage variable of pillar " $\mathrm{i}$ ” in country “ $\mathrm{j}$ ”.

Number of disadvantage variable of pillar "i" in country " $\mathrm{j}$ ".

b) A shaded cell represents the ratio which its value is greater than one.

Fortunately, variables that supported the strength of banking system in Thailand were on pillars that directly related to the banking sector; they are Banking financial services and Financial access. This help explains why Thailand's financial system was ranked the third in ASEAN. Most of the disadvantageous variables which will be the negative factors for Thailand in the long run, were found in 3 supporting services of the banking system; Institutional environment, Business environment, and Banking system stability (sub-pillar). For other AEC, Vietnam was the weakest among the six countries, followed by the Philippines and Indonesia. The Index showed that only Singapore and Thailand earned the highest strength in pillars 4 and pillar 7. Vietnam, on the other hand, had a greater number of the advantage than disadvantage variables in driving "banking financial services", and Malaysia had higher strength in Pillar 7 than in Pillar 4. For banking sector, Indonesia and Philippines seemed to be the weakest among countries studied.

\subsubsection{Banking Financial Services (Pillar 4)}

Index in the pillar 4 was designed to measure financial services provided by the banking system of the country; they were size index, efficiency index, and financial information disclosure, which altogether were expressed in 14 variables as shown in Table 8. Among AEC, this pillar supported strength in the financial sector of Malaysia (11th), Thailand (28th), and Vietnam (32th). However, this phenomenon may not prolong in Malaysia, because the country does not have a sufficient number of advantageous factors in driving its strength in the long run; as the ratio of advantageous variable to the disadvantageous variable was less than 1 (Table 8). For Singapore, even though the pillar rank was worse than the country rank, the ratio was greater than 1, shedding hope for a better position in the long run. Indonesia and Philippines were the weakest in these services.

For Thailand, the "Banking financial services" was considered the most competitive in AEC; there were 10 out of 14 variables that were the positive factors for banking development. Of the three index which were Size index, Efficiency index, and Financial information disclosure, it is worth noting that most factors that support pillar 4 
were variables in the category of "Size Index" (Table 9).

\section{(a) Size Index}

The "size index" displays the overall value of financial assets related to banking services. The larger the banking system, the more capital it can channel from savers to investors (Chinn, (2007), the better the rank of "size index" as well as degree of bank competitiveness. Measures of size include variables such as deposit money bank assets to GDP, M2 to GDP, and private credit to GDP, as shown in Table 8. The only weak variable in this category was the size of money market instruments which was rather small and approach to zero as compared to GDP. Among ASEAN countries, Singapore was the only country of which the score of "size of money market instruments to GDP" was compatible with the world and was ranked at the 9th. For other members of AEC, the size of money market instruments was also small.

Table 9. Comparison of Banking Financial Services (Pillar 4) among the AEC

\begin{tabular}{|c|c|c|c|c|c|c|}
\hline \multirow{2}{*}{ Rank of FDI 2012} & \multicolumn{6}{|c|}{ Rank (Out of 62) } \\
\hline & Indonesia & Malaysia & Philippines & Singapore & Thailand & Vietnam \\
\hline 4th pillar: Banking financial services & 53 & 11 & 49 & 10 & 28 & 32 \\
\hline Size index & 50 & 18 & 44 & 9 & 24 & 33 \\
\hline Deposit money bank assets to GDP & 54 & 19 & 49 & 20 & 24 & 21 \\
\hline Central bank assets to GDP & 14 & 42 & 22 & 25 & 23 & 15 \\
\hline Financial system deposits to GDP & 47 & 12 & 40 & 10 & 25 & 58 \\
\hline M2 to GDP & 52 & 9 & 48 & 10 & 12 & 16 \\
\hline Private credit to GDP & 53 & 22 & 52 & 26 & 20 & 21 \\
\hline Bank deposits to GDP & 48 & 12 & 42 & 10 & 25 & 59 \\
\hline Money market instruments to GDP & 33 & 33 & 33 & 9 & 33 & 33 \\
\hline Efficiency index & 48 & 27 & 33 & 6 & 17 & 15 \\
\hline Aggregate profitability indicator & 24 & 13 & 42 & 6 & 20 & 7 \\
\hline Bank overhead costs & 50 & 21 & 47 & 15 & 34 & 24 \\
\hline Public ownership of banks & 57 & 54 & 29 & 48 & 37 & 43 \\
\hline Bank operating costs to assets & 51 & 23 & 43 & 11 & 33 & 21 \\
\hline Non-performing bank loans to total loans & 15 & 22 & 29 & 7 & 27 & $\mathrm{n} / \mathrm{a}$ \\
\hline Financial information disclosure & 41 & 2 & 54 & 32 & 37 & 43 \\
\hline Private credit bureau coverage & 53 & 17 & 48 & 25 & 30 & 53 \\
\hline Public credit registry coverage & 10 & 5 & 26 & 26 & 26 & 11 \\
\hline Advantage variables & 4 & 6 & 4 & 8 & 10 & 8 \\
\hline Disadvantage variable & 10 & 8 & 10 & 6 & 4 & 6 \\
\hline
\end{tabular}

Note: Shaded variable represents indicator that was a disadvantage to banking development and unshaded variable stands for an index that was an advantage for banking development.

\section{(b) Efficiency Index}

The role of banking system in financing the economy requires banking system to operate efficiently. Efficient banking system means it can provide service financing at lower cost (Mongid \& Kurniadi, 2014). Efficiency index in the Report includes aggregate profitability indicator, bank overhead costs, bank operating costs to assets, and the ratio of non-performing loans to total loans (Table 8). For this indicator, Thailand was ranked 17th, and was the third in AEC after Singapore (6th) and Vietnam (15th). Malaysia was ranked at 27th behind Thailand because there were too many public banks in the country as shown in Table 2.

In the Report, a country with high government ownership of banks tends to be scored less. Thailand, Malaysia together with another AEC has no exception. For Thailand, government ownership banks were known as Specialized Financial Institutions (SFIs). The existence of SFIs was not for enhancing country growth or competitiveness. Currently, SFIs serve market niches that do not adequately reached by traditional financial institutions and help build private markets, generate tax revenues and empower poor people (Note 3). If the results of publicly owned banks will lead to being less efficient, impeding credit allocation and the channeling of capital, and slowing banking operation as suggested by Xiao and Zhao (2011); almost all AEC countries tend to have the same barrier in enhancing their competitiveness. 
In 2012, the ratio of average nonperforming bank loans to total in most of the AEC members except Vietnam was less than $4 \%$, implying that, on average, the commercial bank in Thailand and another four countries were operating efficiently and meet the international standards.

Two variables were used to measure bank performance: bank overhead costs and bank operating costs to assets. From Table 8, the banks in Thailand were highly profitable even though performs poorly in the operational measures; these due to policy objectives that strictly put control on low ratio of non-performing bank loans to total loans, and partly may due to the degree of less competition among bank within the country. Regarding comparison among AEC countries, almost every bank in AEC performs well in earning profit except the Philippines, indicating the unreadiness of Philippines' bank to face tougher competition.

\section{(c) Financial Information Disclosure}

A Third key aspect of the efficacy of the banking system was the role of the financial information disclosure within the operation of banks. Barth et al. (1999) suggest that policies that induce proper information disclosure authorize private-sector corporate control of banks, and motivate private agents to exercise corporate control, tend to encourage bank development, operational efficiency, and stability.

In the Report, the sub-pillar of "Financial information disclosure" was expressed by two variables; Private credit bureau coverage and Public credit registry coverage. Among AEC, Malaysia earns the highest score in this pillar, and Thailand rank was at 37th lagged behind Malaysia (2nd) and Singapore (32th).

\subsubsection{Financial Access (Pillar 7)}

Financial access promotes growth through the provision of credit to both new and existing businesses and household. It benefits the economy in general by accelerating economic growth, intensifying competition, as well as boosting demand for labor (Beck, Levine, \& Levkov, 2010). The lack of financial access limits the range of services and credits for household and enterprises. Poor individuals and small businesses have to rely on their personal wealth or internal resources to invest in their education and businesses, which limits their full potential and leads to the cycle of persistent inequality and diminished growth (Demirgüç-Kunt, Beck, \& Honohan, 2008).

Table 10. Comparison of Financial Acces (Pillar 7) among the AEC

\begin{tabular}{|c|c|c|c|c|c|c|}
\hline \multirow{2}{*}{ Rank of FDI 2012} & \multicolumn{6}{|c|}{ Rank (Out of 62) } \\
\hline & Indonesia & Malaysia & Philippines & Singapore & Thailand & Vietnam \\
\hline 7th pillar: Financial access & 54 & 28 & 53 & 14 & 25 & 43 \\
\hline Commercial access & 23 & 6 & 38 & 2 & 24 & 43 \\
\hline Financial market sophistication & 45 & 22 & 36 & 6 & 30 & 61 \\
\hline Venture capital availability & 17 & 9 & 39 & 3 & 33 & 51 \\
\hline Ease of access to credit & 33 & 5 & 25 & 2 & 19 & 47 \\
\hline Financing through local equity mkt. & 23 & 6 & 29 & 3 & 21 & 47 \\
\hline Ease of access to loans & 11 & 7 & 28 & 2 & 21 & 50 \\
\hline Foreign direct investment to GDP & 33 & 17 & 56 & 2 & 27 & 8 \\
\hline Retail access & 56 & 35 & 48 & 31 & 25 & 36 \\
\hline Market penetration of bank accounts & 57 & 29 & 52 & 6 & 26 & 55 \\
\hline Commercial bank branches & 42 & 37 & 43 & 38 & 35 & 50 \\
\hline Total number of ATMs & 44 & 31 & 43 & 27 & 19 & 42 \\
\hline Total number of point of sale (POS) devices & 55 & 42 & 50 & 39 & 26 & 48 \\
\hline Loan from a financial institution & 35 & 24 & 26 & 28 & 8 & 14 \\
\hline Advantage variables & 4 & 5 & 4 & 7 & 9 & 2 \\
\hline Disadvantage variable & 7 & 6 & 7 & 4 & 2 & 9 \\
\hline Ratio of advantage to dis advantage variables & 0.6 & 0.8 & 0.6 & 1.8 & 4.5 & 0.2 \\
\hline
\end{tabular}

Note: Shaded variable represents indicator that was a disadvantage to banking development and unshaded variable stands for an index that was an advantage for banking development. 
The Report categorizes accessibility to banking into two channels; Commercial access and Retail access. Singapore, Thailand, and Malaysia were competitive in providing services access to capital through both commercial and retail channels and were expected to be robust in the long run since the ratio of advantage to disadvantage variable was greater than 1 in all three countries (Table 10). Thailand's score was the second highest in AEC after Singapore (14th), beat Malaysia (28th) that go to the third this time. Malaysia was weak in Retail access of which every variable in this sub-pillar was disadvantageous for bank competitiveness.

For Thailand, the only negative factor in Commercial access was the laggard in developing venture capital industry which significantly stays behind after Singapore and Malaysia. Lyons (2007) pointed out that Thailand was not an attractive environment for venture capital investing. Because English-language competency was competent only in some educated group, the Thai legal and financial systems were closer to those of Continental Europe rather than the Anglo-American system. Also, Thailand lags both Singapore and Malaysia regarding transparency, corruption, and a predictable legal system.

For Retail access, the only weak variable for Thai banking system was "Commercial bank branches." Commercial bank branches for Thailand were considered too few to support country financial development. However, Thailand earns the highest score among AEC and hence was not considered as detrimental to Thai bank competitiveness under AEC financial liberalization in this study

\subsubsection{Bank Foundational Factors}

Conceptually, a country with low fundamental characteristics to support banking system could limit bank capability to growth and competitiveness in the opened financial system. Factors covering these structural features as proposed in the Report were the Institutional environment, the Business environment, and the Degree of financial stability. Table 10 showed that except Singapore, every AEC member countries were weak in Pillar 1- Institutional environment, Pillar 2- Business environment, and a sub-pillar of Pillar 3 - banking system stability.

\section{(a) Institutional Environment (Pillar 1)}

Theoretically, a healthy institutional environment lessens information and transaction costs (Levine, 2004), and was likely to contribute to a more efficient financial sector (Mishkins, 2001). Singapore scores best in this pillar not only in AEC countries but also the 62 countries. Thailand was ranked at the third among AEC after Malaysia, as shown in Table 11.

Table 11. Advantage and disadvantage variables for supporting indicators (Pillar 1-3) among the AEC

\begin{tabular}{lcccccc}
\hline & Indonesia & Malaysia & Philippines & Singapore & Thailand & Vietnam \\
\hline 1st pillar: Institutional environment & $\mathbf{5 1}$ & $\mathbf{2 1}$ & $\mathbf{3 9}$ & $\mathbf{1}$ & $\mathbf{3 3}$ & $\mathbf{5 3}$ \\
Financial sector liberalization & 54 & 29 & 30 & 19 & 33 & 51 \\
Corporate governance & 51 & 21 & 39 & 1 & 33 & 53 \\
Legal and regulatory issues & 41 & 19 & 48 & 1 & 39 & 52 \\
Contract enforcement & 54 & 13 & 57 & 1 & 23 & 42 \\
2nd pillar: Business environment & $\mathbf{5 3}$ & $\mathbf{2 5}$ & $\mathbf{5 4}$ & $\mathbf{1}$ & $\mathbf{4 5}$ & $\mathbf{5 6}$ \\
Human capital & 40 & 18 & 42 & 3 & 32 & 59 \\
Taxes & 37 & 25 & 41 & 7 & 29 & 56 \\
Infrastructure & 53 & 35 & 55 & 13 & 46 & 50 \\
Cost of doing business & 61 & 30 & 60 & 1 & 50 & 52 \\
3rd pillar: Financial stability & $\mathbf{3 5}$ & $\mathbf{1 0}$ & $\mathbf{4 7}$ & $\mathbf{1}$ & $\mathbf{3 4}$ & $\mathbf{5 6}$ \\
Currency Stability & 12 & 3 & 32 & 2 & 8 & 49 \\
Banking system stability & 48 & 29 & 54 & 8 & 56 & 46 \\
Aggregate measure of real estate bubbles & 17 & 12 & 43 & 45 & 24 & N/A \\
Risk of sovereign debt crisis & 37 & 22 & 39 & 21 & 35 & 51 \\
\hline
\end{tabular}

Note. Shaded figures represent disadvantage variables, and un-shaded ones stand for advantage variables.

Theoretically, financial liberalization permits a greater degree of financial depth that translates into a larger number of financial intermediation for savers and investors, and results in a more efficient flow of resources to the banking system (Fitzgerald, 2007). Singapore was ranked world number one in this sub-pillar with the help of 2 driving forces "Capital account openness" and "Domestic financial sector"; unfortunately, a failure to follow commitments to WTO agreement on trade in services downgrade her rank in these sub-pillars to 19th. The 
domestic financial sector in almost every country was ready for liberalization except Indonesia and Vietnam, which was still after the financial development path. Strict control in capital account openness drives down scores of both Thailand (53th) and Philippines (52th) to the bottom of the Financial Development Index among the six ASEAN countries.

For the last three variables, it is widely believed that high-quality in corporate governance, the presence of legal institutions that safeguard the interests of investors, and contract enforcement would limits the scope for default among debtors and encouraged banking development (Goldsmith, 1969; Bekaert \& Harvey,2005; Tavares, 2002). Among countries in ASEAN, except Singapore, most variables in this pillar revealed their poor performance. The only advantage variable in supporting competitiveness for Thailand and Malaysia was "Contract enforcement"; the variable represented the cost of enforcing contracts as a percent of the legal claim (Table 11).

\section{(b) Business environment (Pillar 2)}

Even though Business environment does not directly relate to the banking sector, but its fundamental characteristics support the development of financial intermediaries, markets, instruments, and services. Singapore was also the world number one in the business environment for the financial sector while other countries were far lag behind (Table 11).

Among the four sub- pillars: Human capital, Taxes, Infrastructure, and Cost of doing business, "Infrastructure" and "Cost of doing business" were the weakest variables for every ASEAN members except Singapore and Malaysia. Thailand as well as others stay almost at the bottom of the world rank. The only factor that supports business environment for Thailand and strengthens the degree of competitiveness was "marginal tax variation" in the sub-pillar "Tax" (Note 2).

\section{(c) Banking system stability (Sub-pillar 3)}

The banking sector was unlike other areas of the economy; competition policy must take account of the interaction between competition and financial stability. Greater competition may be good for efficiency in the short run, but bad for financial stability, in the long term, where liberalization and unfettered competition have resulted in fragility (Allen \& Gale, 2004).

In this sub- pillar, Thailand was ranked at the $56^{\text {th }}$, almost at the bottom of the world rank in 2012 . Because Thailand used to go through financial crises in 1997, and the evaluation of the systemic banking crises sub-pillar combines measures of historic banking system instability, an assessment of aggregate balance sheet strength, and the presence of real estate "bubbles". Such a result does not have any relationship with the degree of competitiveness for banking in Thailand. It was pointed out by Beck, et al. (2008) that the relationship between competition and financial stability was ambiguous in general, and Stijn Claessens (2009), on the other hand, suggested that the relationship between competition and financial stability was considerably more complex than simple "trade-off."

\subsubsection{Factors that Supporting Banking Sector of Thailand Compared to Other ASEAN Countries}

It is worth summarizing here that, for the "Banking Indicator," Thailand is ranked at the third in the pillar of "Banking financial services" after Singapore and Malaysia but is at the 28th of the world. Factors underlying the "Banking financial services" for Thailand were considered advantageous for competition. Of the three index: size index, efficiency index, and financial information disclosure, it is found that 10 out of 14 variables were supporting factors for the development of banking sector. To improve her readiness, Thailand has to develop her money market instruments and the bank efficiency in reducing overhead and operating costs. Pillar of the "Financial access", on the other hand, showed that the pillar score for Thailand was the second highest in AEC after Singapore and beat Malaysia. With the greatest number of advantageous variables in this pillar among ASEAN countries, it is possible for Thailand in paving the way to a higher degree of competition in financial accessibility in the future. The only weak variable in this pillar was the laggard in developing venture capital industry.

Pillars that portray essential features of Thai banking sector in the "Supporting Indicator" were rather weak. Competency of Thai banking either in banking services or financial access so far has got very few supports from these foundational factors.

\subsection{The Trend of Competitiveness}

Following the criteria imposed on constructing the "Readiness Index" from Table 6, results in Table 12 showed that the pillar of "Banking financial services" for every country had a trend of score improvement. However, only three countries: Singapore, Malaysia, and Thailand were ready for competition in mode A1, while Indonesia, 
Philippines, and Vietnam were in the mode of A2.

For the pillar of "Financial access", there were only three countries that have the promising trend, namely Philippines, Singapore, and Thailand. Malaysia score in this pillar was less than Thailand in both commercial access and retail access; the pillar trend was decreasing and owing disadvantage feature (B2). The results implied that Thailand is most ready for competition in this pillar (A1).

For the three foundational pillars (pillar 1-2 and sub-pillar 3) that defined as the "Supporting Indicator," it appeared that Singapore was best in these pillars in mode A1 while Thailand was in mode B2. For Thailand, the score was decreasing in "Business environment" and "Banking system stability", the most detrimental factors for the pillar of "Business environment" were "Infrastructure" and "Cost of doing business".

\subsection{The Readiness of Banking Sector for Thailand}

In this part, the "Readiness Index" was used in evaluating whether Thai Banking is ready for competition under financial openness in the long run. To draw such a conclusion for Thailand compared to other ASEAN countries, two indicators; ratio of advantage to disadvantage variable and ratio of increasing to decreasing trend variables were used. As mentioned before that, a country with the high ratio of both indicators will be more ready to face regional economic integration under AEC's Financial Liberalization than a country with the lower ratio, because it showed the higher number of variables/factors in driving its banking competency. Following the above assumption, it is summarized in Table 12 that Singapore is the readiest country for regional competition; with both ratios are greater than one, and most of the variables explaining each pillar are in mode either A1 or A2.

Thailand, Malaysia, and the Philippines are not quite ready for AEC financial liberalization. The ratio of advantage to disadvantage variables for the banking sector is lower than 1, indicating that most factors included in the pillars are weak in driving their banking industry. However, the ratio of variables with increasing to decreasing trend of these three countries was greater than 1; implying the strength for future competition. Finally, results displayed that both Indonesia and Vietnam were in the risky mode in losing her competitiveness in the long run. The status of readiness for AEC financial liberalization of each country is illustrated in Table 13.

Table 12. Trends of competitiveness and readiness index among AEC

\begin{tabular}{|c|l|c|c|c|c|c|c|}
\hline & & Indonesia & Malaysia & Philippines & Singapore & Thailand & Vietnam \\
\hline & Rank of FDI 2012 Index & 50 & 18 & 49 & 4 & 34 & 52 \\
\hline $\mathbf{1}$ & 1st pillar: Institutional environment & $\mathrm{A} 2$ & $\mathrm{~A} 2$ & $\mathrm{~A} 2$ & $\mathrm{~A} 1$ & unchange & $\mathrm{B} 2$ \\
\hline 1.1 & Financial sector liberalization & $\mathrm{A} 2$ & $\mathrm{~A} 2$ & $\mathrm{~A} 1$ & $\mathrm{~A} 2$ & $\mathrm{~A} 2$ & $\mathrm{~A} 2$ \\
\hline 1.2 & Corporate governance & $\mathrm{A} 2$ & $\mathrm{~B} 2$ & $\mathrm{~A} 2$ & $\mathrm{~B} 2$ & $\mathrm{~B} 2$ & $\mathrm{~B} 2$ \\
\hline 1.3 & Legal and regulatory issues & $\mathrm{A} 2$ & $\mathrm{~A} 2$ & $\mathrm{~A} 2$ & $\mathrm{~A} 1$ & $\mathrm{~A} 2$ & $\mathrm{~A} 2$ \\
\hline 1.4 & Contract enforcement & $\mathrm{B} 2$ & $\mathrm{~A} 1$ & $\mathrm{~A} 2$ & $\mathrm{~B} 1$ & $\mathrm{~B} 1$ & $\mathrm{~B} 2$ \\
\hline $\mathbf{2}$ & 2nd pillar: Business environment & $\mathrm{A} 2$ & $\mathrm{~A} 2$ & $\mathrm{~A} 2$ & unchange & $\mathrm{B} 2$ & $\mathrm{~B} 2$ \\
\hline 2.1 & Human capital & $\mathrm{A} 2$ & $\mathrm{~A} 2$ & $\mathrm{~A} 2$ & $\mathrm{~A} 1$ & $\mathrm{~B} 2$ & $\mathrm{~B} 2$ \\
\hline 2.2 & Taxes & $\mathrm{A} 2$ & $\mathrm{~A} 2$ & $\mathrm{~A} 2$ & $\mathrm{~A} 1$ & $\mathrm{~A} 1$ & unchange \\
\hline 2.3 & Infrastructure & $\mathrm{B} 2$ & $\mathrm{~A} 2$ & $\mathrm{~B} 2$ & $\mathrm{~A} 2$ & $\mathrm{~B} 2$ & $\mathrm{~B} 2$ \\
\hline 2.4 & Cost of doing business & $\mathrm{B} 2$ & $\mathrm{~A} 2$ & $\mathrm{~B} 2$ & $\mathrm{~A} 1$ & $\mathrm{~B} 2$ & $\mathrm{~B} 2$ \\
\hline $\mathbf{3}$ & 3rd pillar: Financial stability & $\mathrm{B} 2$ & $\mathrm{~A} 1$ & $\mathrm{~B} 2$ & $\mathrm{~A} 2$ & $\mathrm{~B} 2$ & $\mathrm{~B} 2$ \\
\hline 3.2 & Banking system stability & $\mathrm{B} 2$ & $\mathrm{~A} 2$ & $\mathrm{~B} 2$ & $\mathrm{~B} 1$ & $\mathrm{~B} 2$ & $\mathrm{~B} 2$ \\
\hline $\mathbf{4}$ & 4th pillar: Banking financial services & $\mathrm{A} 2$ & $\mathrm{~A} 1$ & $\mathrm{~A} 2$ & $\mathrm{~A} 2$ & $\mathrm{~A} 1$ & $\mathrm{~A} 1$ \\
\hline 4.1 & Size index & $\mathrm{A} 2$ & $\mathrm{~A} 2$ & $\mathrm{~A} 2$ & $\mathrm{~A} 1$ & $\mathrm{~A} 1$ & $\mathrm{~A} 2$ \\
\hline 4.2 & Efficiency index & $\mathrm{B} 2$ & $\mathrm{~B} 2$ & unchange & $\mathrm{A} 1$ & $\mathrm{~A} 1$ & $\mathrm{~B} 1$ \\
\hline 4.3 & Financial information disclosure & $\mathrm{B} 2$ & $\mathrm{~A} 1$ & $\mathrm{~B} 2$ & $\mathrm{~A} 2$ & $\mathrm{~A} 2$ & $\mathrm{~B} 2$ \\
\hline $\mathbf{7}$ & 7th pillar: Financial access & $\mathrm{B} 2$ & $\mathrm{~B} 2$ & $\mathrm{~A} 2$ & $\mathrm{~A} 2$ & $\mathrm{~A} 1$ & $\mathrm{~B} 2$ \\
\hline 7.1 & Commercial access & $\mathrm{B} 1$ & $\mathrm{~A} 1$ & $\mathrm{~A} 2$ & $\mathrm{~A} 1$ & $\mathrm{~A} 1$ & $\mathrm{~B} 2$ \\
\hline 7.2 & Retail access & $\mathrm{B} 2$ & $\mathrm{~B} 2$ & $\mathrm{~A} 2$ & $\mathrm{~A} 2$ & $\mathrm{~A} 1$ & $\mathrm{~B} 2$ \\
\hline & Ratio of increasing to decreasing trends & 0.75 & 3.67 & 2.25 & 3.67 & 1.33 & 0.3 \\
\hline & Ratio of advantage to disadvantage variable & 0.41 & 0.88 & 0.39 & 2.16 & 0.68 & 0.34 \\
\hline
\end{tabular}

Note. The shaded figure represents disadvantage variables and un-shaded stands for advantage variables. Source. Financial Development Report, 2009-2012. 
Table 13. Classification of bank in ASEAN SIX by readiness index

\begin{tabular}{ccc}
\hline \multirow{2}{*}{ Trend } & \multicolumn{2}{c}{ Development Challenges } \\
\cline { 2 - 3 } & advantage & disadvantage \\
\hline Rising & Singapore (A1) & Thailand, Malaysia, Philippines (A2) \\
Declining/Stable & & Indonesia, Viet Nam (B2) \\
\hline
\end{tabular}

\section{Is Thai Banking Ready for AEC Financial Liberalization in 2020?}

To sum up, the bank is by far the most important type of financial institutions in Thailand and other ASEAN members. By using Financial Development Index in assessing Thai bank readiness for AEC Financial Liberalization, this paper evaluates four pillars and one sub-pillar in the financial system. Two of them were pillars that related to banking system directly: Banking financial services (pillar 4) and Financial access (pillar 7) Another three were pillars that indicated underlying factors of bank competitiveness: Institutional environment (pillar 1), Business environment (pillar 2), and sub-pillar of "Banking system stability" (pillar 3).

Upon assessing Thai banking's readiness for regional competition by using readiness index constructed in this study, results show that Singapore's banking system is the readiest country for regional competition, followed by Malaysia, Thailand and Philippines. The banking sector in Thailand is not quite ready for AEC financial liberalization. Even though Thailand performs quite well across the banking pillars, there are still several areas of concern, namely, a decrease in financial stability (34th) driven by an increase in the risk of sovereign debt crisis (35th) and banking system instability (56th). The variables that threaten Thai banking for future competitiveness are "Legal and regulatory issues $\left(39^{\text {th }}\right)$," which are in the category of the "Institutional environment $\left(33^{\text {rd }}\right)$." Moreover, the "Infrastructure ( $\left.46^{\text {th }}\right)$ " and the "Cost of doing business $\left(50^{\text {th }}\right)$ " in the "Business environment" $\left(45^{\text {th }}\right)$ are also not the promising factors for supporting the banking system in Thailand for the long run. The Thai government should be proud of her current strength in the banking sector, but also improve all the negative aspects that can threaten Thai bank competitiveness in the future.

\section{Acknowledgements}

This paper is part of a research project titled "Readiness of Thai Banking under AEC's Financial Liberalization in 2015. The research was under the supervision of Research Center, National Institute of Development Administration, Bangkok, Thailand in 2013. I humbly extend my thanks to all concerned persons who co-operated with me in this research work. In addition, I wish to take this opportunity to record sincere thanks to my colleague, Mrs. Chiraporn Sumetheprasit, who assisted in conducting the research. I am extremely grateful and indebted to her for her expert, sincere and valuable guidance and encouragement extend to me.

\section{References}

Asian Development Bank Thailand. (2011, September). Restructuring of Specialized Financial Institutions, Performance Evaluation Report, Reference Number: PPE: THA 2011-22, Project Number: 32437, Loan Number: 1735. Retrieved from http://www.adb.org/sites/default/files/evaluation-document/35072/files/ 32437-01-tha-pper.pdf

Barth, J. R., Caprio, G., \& Levine, R. (1999). Banking Systems Around the World: Do Regulation and Ownership Affect Performance and Stability. World Bank Policy Research, No.2325. Washington DC: World Bank. Retrieved from http://www-wds.worldbank.org/servlet/WDSContentServer/WDSP/IB/2000/ 05/25/000094946_00050606015069/Rendered/PDF/multi_page.pdf

Besanko, D., \& Thakor, A. V. (1992). Banking deregulation: Allocational consequences of relaxing entry barriers. Journal of Banking \& Finance, 16(5), 909-932. Retrieved from https://ideas.repec.org/f/pbe431.html

Chinn, M. (2007). East Asia and Global Imbalances: Saving, Investment, and Financial Development. National Bureau of Economic Research, 18, 117-150. Retrieved from http://www.nber.org/papers/w13364.pdf

Claessens, S. (2009). Competition in the Financial Sector: Overview of Competition Policies. MyIDEAS. Retrieved from http://www.imf.org/external/pubs/cat/longres.aspx?sk=22727

Dell'Ariccia, G., Igan, D., \& Laeven, L. (2008). Credit Booms and Lending Standards: Evidence from the Subprime Mortgage Market. International Monetary Fund. Retrieved from https://www.imf.org/external/ pubs/cat/longres.aspx?sk=21900.0

Demirgüç-Kunt, A., Beck, T., \& Honohan, P. (2008). Finance for All: Policies and Pitfalls in Expanding Access. 
Washington, D.C.: The World Bank. Retrieved from http://siteresources.worldbank.org/INTFINFORALL/ Resources/4099583-1194373512632/FFA_book.pdf

Dominguez, G. (2015, March 23). ASEAN banking accord 'a key step towards economic integration. Retrieved from http://www.dw.com/en/asean-banking-accord-a-key-step-towards-economic-integration/a-18333763

Franklin, A., \& Gale, D. (2004). Competition and Financial Stability. Journal of Money, Credit and Banking, 2, 453-480.

Franklin, A., \& Gale, D. (2007). Understanding Financial Crises. Oxford, U.K.: Oxford University Press.

Groff, S. (2014, June 23). ASEAN Integration and the Private Sector. Speech presented by ADB Vice-President in Berlin, Federal Republic of Germany. Retrieved from http://www.adb.org $/ \mathrm{km} / \mathrm{node} / 41820$

Lyons, K., \& Kenney, M. (2007, December 15). The Malaysian Venture Capital Industry. Prepared for Shahid Yusuf and Kaoru Nabeshima of the World Bank, Department of Human and Community Development, University of California, Davis, Davis, California 95616.

Mongid, A., \& Kurniadi, D. (2014). The Determinants of Commercial Bank's Cost Inefficiency: Evidences from Asean Banking Market. http://dx.doi.org/10.2139/ssrn.2484350

Wai-Mun, H. L. Teck-Heang, L., \& Cai-Lian, T. (2011). Readiness of ASEAN Banking Sector Integration: Recent Development and Statistical Evidence. The IUP Journal of Monetary Economics, 9(1), 46-65. Retrieved from https://ideas.repec.org/s/icf/icfjmo.html

Xiao, S., \& Zhao, S. (2011). How Do Agency Problems Affect Firm Value? Evidence from China. http://dx.doi.org/10.2139/ssrn.1865306

Hawksford. (2015). Banking Industry and Major Banks in Singapore. Retrieved from http://www.guidemesinga pore.com/doing-business/finances/singapore-banking-industry-overview

Sato, Y. (2005). Bank Restructuring and Financial Institution Reform in Indonesia. The Developing Economies, XLIII-1, 91-120. Retrieved from http://www.ide.go.jp/English/Publish/Periodicals/De/pdf/05_01_05.pdf

Vora-Sittha, P., \& Chiraporn, S. (2013). Readiness of Thai Banking under AEC's Financial Liberalization in 2015. Research Center, National Institute of Development Administration, Bangkok, Thailand.

World Bank. (2006). Financial Sector Development Indicators, Comprehensive assessment through enhanced information capacity. Financial Sector Operations and Policy. Retrieved from http://data.worldbank.org/ data-catalog/world-development-indicators

World Economic Forum. (2009-2012). The Financial Development Report 2009-2012. Official websites and annual reports of ASEAN central banks and financial supervisory agencies. Retrieved from http://www3.weforum.org/docs/WEF_FinancialDevelopmentReport_2012.pdf

\section{Notes}

Note 1. Data are from Country/Economy Profiles in the Financial Development Report 2012, p. 148, 188, 224,248, 276 and 304, and the Official websites and annual reports of ASEAN central banks and financial supervisory agencies.

Note 2. Marginal tax variation is the variation between the top tax rate on corporate income and the taxes and mandatory contributions paid by a prototypical business as a percent of commercial profits.

Note 3. Thailand: Rationalization and Corporate Governance of ... (n. d.). Retrieved from http://www.mfdr.org/Sourcebook/1st Edition/6-4Thailand-Rationalization.pdf

\section{Appendix A}

\section{The Seven Pillars of Financial Development Indicators}

In the Report, various aspects of the impetus for financial development can be seen as seven pillars, grouped into three broad categories with 25 indicators as shown in Table 4. The first category is "Factors, policies, and institutions", it covers the first three pillars that explain essential features supporting financial intermediation including banking system. The second category named "Financial intermediation" contains pillar 4 to 6 , it measures the degree of development of the financial sector, as expressed in the different types of intermediaries. The third category comprises of only pillar 7 (Financial access) which spans areas of access to capital through 
both commercial and retail channels.

Table A1. Financial Development Indicators for 7 Pillars

\begin{tabular}{|c|l|r|l|}
\hline I & Factors, policies, and institutions & II & Financial intermediation \\
\hline $\mathbf{1}$ & 1st pillar: Institutional environment & $\mathbf{4}$ & 4th pillar: Banking financial services \\
\hline 1.1 & Financial sector liberalization & 4.1 & Size index \\
\hline 1.2 & Corporate governance & 4.2 & Efficiency index \\
\hline 1.3 & Legal and regulatory issues & 4.3 & Financial information disclosure \\
\hline 1.4 & Contract enforcement & $\mathbf{5}$ & 5th pillar: Non-banking financial services \\
\hline $\mathbf{2}$ & 2nd pillar: Business environment & 5.1 & IPO activity \\
\hline 2.1 & Human capital & 5.2 & M\&A activity \\
\hline 2.2 & Taxes & 5.3 & Insurance \\
\hline 2.3 & Infrastructure & 5.4 & Securitization \\
\hline 2.4 & Cost of doing business & $\mathbf{6}$ & 6th pillar: Financial markets \\
\hline $\mathbf{3}$ & $\mathbf{3 r d}$ pillar: Financial stability & 6.1 & Foreign exchange markets \\
\hline 3.1 & Currency Stability & 6.2 & Derivatives markets \\
\hline 3.2 & Banking system stability & 6.3 & Equity market development \\
\hline 3.3 & Aggregate measure of real estate bubbles & 6.4 & Bond market development \\
\hline 3.4 & Risk of sovereign debt crisis & III & Financial access \\
\hline & & $\mathbf{7}$ & $\mathbf{7 t h}$ pillar: Financial access \\
\cline { 3 - 5 } & & 7.1 & Commercial access \\
\cline { 2 - 4 } & & 7.2 & Retail access \\
\hline
\end{tabular}

Note. a) Details of each variable can be found in "Technical Notes and Sources" from WEF (2013, p. 385).

b) The shaded variables and pillars are the ones being use in this study.

Source. The Financial Development Report 2012, World Economic Forum USA Inc. New York, USA.

\section{Copyrights}

Copyright for this article is retained by the author(s), with first publication rights granted to the journal.

This is an open-access article distributed under the terms and conditions of the Creative Commons Attribution license (http://creativecommons.org/licenses/by/3.0/). 